INSIGHTS INTO REGIONAL DEVELOPMENT

ISSN 2669-0195 (online) http://jssidoi.org/IRD/

2020 Volume 2 Number 2 (June)

http://doi.org/10.9770/IRD.2020.2.2(6)
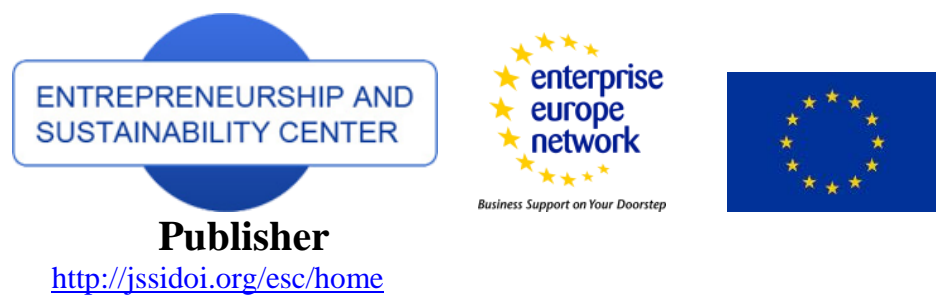

Business Support on Your Doorstep

http://jssidoi.org/esc/home

\title{
A COMPARATIVE STUDY OF PERFORMANCE OF COMMERCIAL BANKS IN ASIAN DEVELOPING AND DEVELOPED COUNTRIES
}

\author{
Asima Siddique ${ }^{1}$, Omar Masood ${ }^{2 *}$, Kiran Javaria ${ }^{3}$, Dinh Tran Ngoc Huy ${ }^{4}$ \\ ${ }^{1}$ Department of Management Science, Comsats University, Islamabad, Pakistan \\ ${ }^{2,3}$ School of Accountancy and Finance, University of Lahore, Islamabad, Pakistan \\ ${ }^{4}$ Banking University, Ho Chi Minh city Vietnam \\ ${ }^{4}$ GSIM, International University of Japan, Niigata, Japan \\ E-mail: ${ }^{2 *}$ masood_omar@hotmail.com (Corresponding author)
}

\begin{abstract}
The main focus of this study is to investigate the impact of non-performing loans (NPLs) and other bank specific factors on the financial performance of commercial banks in Asian developing and developed countries due to an alarmingly high ratio of non-performing loans. The bank specific factors that are used in this study are cost efficiency ratio (CER), capital adequacy ratio (CAR), size of the bank, sales growth (SG) and proxies of financial performance (FP) are return on equity (ROA) and return on asset (ROE). Secondary Panel data of ten years (2006-2015) has been used for this empirical analysis and 19 commercial banks from developing countries of Asia (Pakistan and India), while 17 commercial banks from developed countries of Asia (Japan and Saudi Arabia) are selected. Generalized method of moment is used for the coefficient estimation to overcome the effects of some endogenous variables. NPLs and CER are significantly negatively related to the financial performance (ROA and ROE) of developing and developed countries commercial banks. There is a negative relationship of bank size with most of financial performance variables. Sale growth and capital adequacy ratio has significant positive relationship both measures of financial performance (ROA and ROE) in both pools. Due to the importance of commercial banks in the overall economy of a country, there is a need for management of commercial banks and regulatory authorities to undertake policies that ensure efficiency in banking operations.
\end{abstract}

Keywords: Non-Performing Loans, micro economic variables, Pakistan \& India, Japan \& Saudi Arabia, GMM approach

Reference to this paper should be made as follows: Siddique, A., Masood, O., Javaria, K., Huy, D.T.N. 2020. A comparative study of performance of commercial banks in ASIAN developing and developed countries. Insights into Regional Development, $2(2), 580-591$. https://doi.org/10.9770/IRD.2020.2.2(6)

JEL Classifications: B21, D00, G21, G15

\section{Introduction}

Around the globe, commercial banks are vital organ of any economy due to their intermediary role and wide ranging financial services that they provide to the community and the nation at large. Well functioning commercial banks increase the economic growth of a country and poor performance of commercial banks increase the chances of failure, eventually leading to financial crisis. Lending is considered the heart of banking industry and by issuing loans commercial banks wants to maximize their earnings (Negera, 2012). Commercial banks want to maximize their lending but poor lending decisions increase the ratio of non-performing loans. According to Berger and DeYoung (1997) non-performing loans (NPLs) are considered a major threat to banking 


\section{INSIGHTS INTO REGIONAL DEVELOPMENT}

ISSN 2669-0195 (online) http://jssidoi.org/jesi/

2020 Volume 2 Number 2 (June)

http://doi.org/10.9770/IRD.2020.2.2(6)

not only in developing countries but also for developed countries. When NPLs increase, it is widely considered that the credit policy of that institution is at fault resulting in the reduction of bank earnings (Saba, kouser, \& Azeem, 2012).

Asia is one of the most important continents of the world and consists of 48 countries. According to the Asian development bank (2016) Asia contributes to 60\% in the world growth. Despite of this growth the ratio of NPLs is alarmingly high in Asia. According to Akhtar, Ali and Sadaqat (2011) the non-performing loans and internal factors (the factors are under the control of management) are main reason for commercial banks failure that even lead to the Asian currency crisis (1997) and crisis subprime crisis (2007). Although in the present environment Asian commercial banks have tried to manage the bank specific factors and non-performing loan ratio has decreased in Asia by $10 \%$ but it is still a serious concern. This ratio of non-performing loan is very high in Asian countries as compared to other developed countries. Despite of a lot of authors (Bloem \& Gorter, 2001; Saba, kouser, \& Azeem, 2012, Chimkono, et al., 2016) have addressed these issues but literature shows that the results of are inconclusive. So, the study aims to further explore the phenomena of NPLs and banks specific factors in a unique comparative study of developed and developing countries from only Asia.

\section{Literature Review}

The literature review section is divided in two parts. First part is theoretical review of dependent and independent variables. In second and last part is empirical review, which is consisting of the relationship NPLs and financial performance and also includes the relationship between bank specific factors and financial performance of a firm.

\subsection{Theoretical Review}

Banking industry is considered the back bone of a country because it is working for the financial stability of all business activity. Subsequent "Basel Accords" have imposed some regulations on the global banking industry, resulting is banking performance improvement but at a same time banking industry has faced some financial crisis for the last few decades. According to Krueger (2000) all financial crisis are the result of non-performing loan. The term of NPLs is firstly used by USA in 1987 after the terrible financial crisis, according to IMF, a loan is considered non-performing when the payment of principle or interest (both at a time) are still due after 90 days or more have been passed.

Balasubramaniam (2012) explains some reasons of Non-Performing Loans (NPLs) Matter. Firstly, it affects the profitability of bank not only short term profitability but also long term profitability. Moreover investments (ROI) also decrease due to the high ratio of NPLs. Secondly, NPLs create liquidity problems in bank resulting reduced loan giving capacity. Thirdly, management spends a lot of time and effort to manage the non-performing asset and it is another indirect cost for banks. Lastly, it is effects the banks creditworthiness leading to lower deposits.

Bank specific variables are banks internal or micro economic variables. According to Adebayo, Adeyanju and Olabode (2011) management can control their internal factors and these variable influence the financial statements of banks directly and indirectly. Unsystematic risk or diversifiable risk is associated with these factors (Masood \& Ashraf, 2012).

\subsection{Empirical review}

\subsubsection{Non performance loan (NLPs) and financial performance of bank}

Several studies have been conducted to investigate the impact of NPLs and banks financial performance (Berger and DeYoung, 1997; MUASYA, 2008; Saba, Kouser, \& Azeem, 2012; Lata, 2015, Chimkono et al., 2016). Saba, 


\section{INSIGHTS INTO REGIONAL DEVELOPMENT}

ISSN 2669-0195 (online) http://jssidoi.org/jesi/

2020 Volume 2 Number 2 (June)

http://doi.org/10.9770/IRD.2020.2.2(6)

kouser and Azeem (2012) found that there significant negative relation between the NPLs and financial performance.

Alshatti (2015) conducted a study on Ghana region to investigate the relationship between credit risk management and profitability of rural banks. Five year panel data (2006 to 2010) where a number banks are ten concludes that there is significant positive relationship between NPLs and financial performance. Lata (2015), conduct the research to investigate the relationship between non performing loan and banks profitability and found that there is a significant negative relationship between non performance loan and banks financial performance. Lipunga (2014) conducted the study on Nigerian banks with secondary data (2006-2012) found that there was no relationship of NPLs and return on asset while there is a significant relationship between non-performing loan and return on equity. There is a negative relationship between NPLs and banks performance (MUASYA, 2008). Other authors (Krueger, 2000; Bloem \& Gorter, 2001; Saba et al., 2012; Chimkono et al., 2016) also concluded on the same issue that there is inverse relationship between NPLs and banks financial performing. It means if NPLs increase then banks financial performance decreases and vice versa.

\subsubsection{Bank specific variable and financial performance of bank}

Bank specific variable are internal factors of the banks and there are different bank specific factors like cost efficiency ratio, size, capital adequacy ratio and sales growth. Cost efficiency ratio indentifies how to efficiently control the cost of a bank. Different research studies show that the cost efficiency ratio (Berger and DeYoung, 1997; Karim, Chan \& Hassan, 2010; Chimkono et al., 2016). Berger and DeYoung (1997) do a study on problem loans and cost efficiency in commercial banks when management have no control on their operation and are not performing well on day to day basis. In this case their loan portfolio decrease and cost efficiency ratio also increase.

Karim et al., (2010) conducted a study to investigate the relationship between NPLs and bank efficiency. This study is based on Malaysian and Singaporean banks data is collected from both banks over the period of 1995 to 2000. Tobit simultaneous equation regression model was used for estimation and result shows that an inverse relationship exists between NPLs and bank efficiency.

Adebayo, Adeyanju and Olabode (2011) investigate the relationship between financial performance and cost efficiency. They collected data of seven years (2000 to 2007) from 29 Sub-Saharan African countries and found insignificant negative relationship between cost efficiency and profitability of a bank. Mausya (2008) conducted a research on South Africa banking sector to check the nature of relationship between cost efficiency and profit efficiency and data was collected from the period of 2000 to 2005. The result of this study proved that there is a weak negative correlation between cost efficiency and profit efficiency. Chimkono et al., (2016) found that there is insignificant positive relationship of cost efficiency ratio and financial performance of commercial banks.

A firm size describes its production capacity and the service that firm is providing to its customer. Goods and services are produced at low price in a large firm as compared to small firms (Masood \& Ashraf, 2012). Masood and Ashraf (2012) conclude that there is a positive association between firm size and profitability of a firm because large firms have a large size of asset through which they get benefit. Saba, kouser and Azeem, (2012) on the other hand conclude that small companies better than large companies. Adebayo, Adeyanju and Olabode (2011) indentify that there is non-significant relationship between firm size and profitability of a firm.

Capital is considered very important for the effective functioning of every business including the banking sector because it has an ability to absorb any loss that is faced by the business and investor have confidence on that business because insolvency risk of that business is low. Every business especially banking industry needs this confidence, so that borrowers give their money without any risk of insolvency or bankruptcy. 
INSIGHTS INTO REGIONAL DEVELOPMENT

ISSN 2669-0195 (online) http://jssidoi.org/jesi/

2020 Volume 2 Number 2 (June)

http://doi.org/10.9770/IRD.2020.2.2(6)

According to Basel accords minimum capital adequacy ratio (8\%) should be maintained by each bank. According to Lipunga (2014) capital is used to help the depositors and counterparties of the financial organization to protect them from the risk that are associated with on-balance sheet items and off-balance sheet items. Therefore positive relationship with financial performance. According to Akhtar, Ali and Sadaqat (2011) and Masood and Ashraf (2012) there is a insignificant negative relationship between capital adequacy ratio and return on equity. According to Delmar, Davidsson and Gartner (2003) in today's world firms are giving much value to the growth of the sales and therefore includes with the statements "We plan that in next five years our company sales would be to double sales," or "Our objective is that our sales of a company would be $\$ 2$ billion during the period of 7 years". They also tell us that the sales growth of company is affected by different variables which include promotion of sales, employees' motivation and retention factors of talented employees. To achieve these goals and keeps employees motivated, companies set a percentage of reward that is given by achieving on specific sales goals. Most of the researchers Delmar, Davidsson and Gartner (2003), Karim et al., (2010), Negera (2012) and Chimkono et al., (2016) conclude that there is positive relationship between sales growth and financial performance of banks. Although some researchers Balasubramaniam (2012) and Alshatti (2015) pointed that there is insignificant and negative relationship between sales growth and financial performance.

\section{Methodology}

This study investigates the impact of nonperforming loans and some bank specific factors (cost efficiency ratio, capital adequacy ratio, sales growth and bank size) on the profitability of commercial banking sector. Panel data has been collected from financial statements of four developed and developing countries of Asia. Developing countries are Pakistan, India and developed countries Japan, Saudi Arabia. The number of banks from Pakistan (10 commercial banks), India (9 commercial banks) Japan (10 commercial banks) and Saudi Arabia (8 commercial banks). The data has been collected from the period of 2006 to 2015, the data of this study is panel in nature. One control variable is inflation whose data has been collected from world bank website. The summary of explanatory variables and dependent variables are given in the table 3.1.

Table 3.1. Summary of explanatory variables and dependent variables

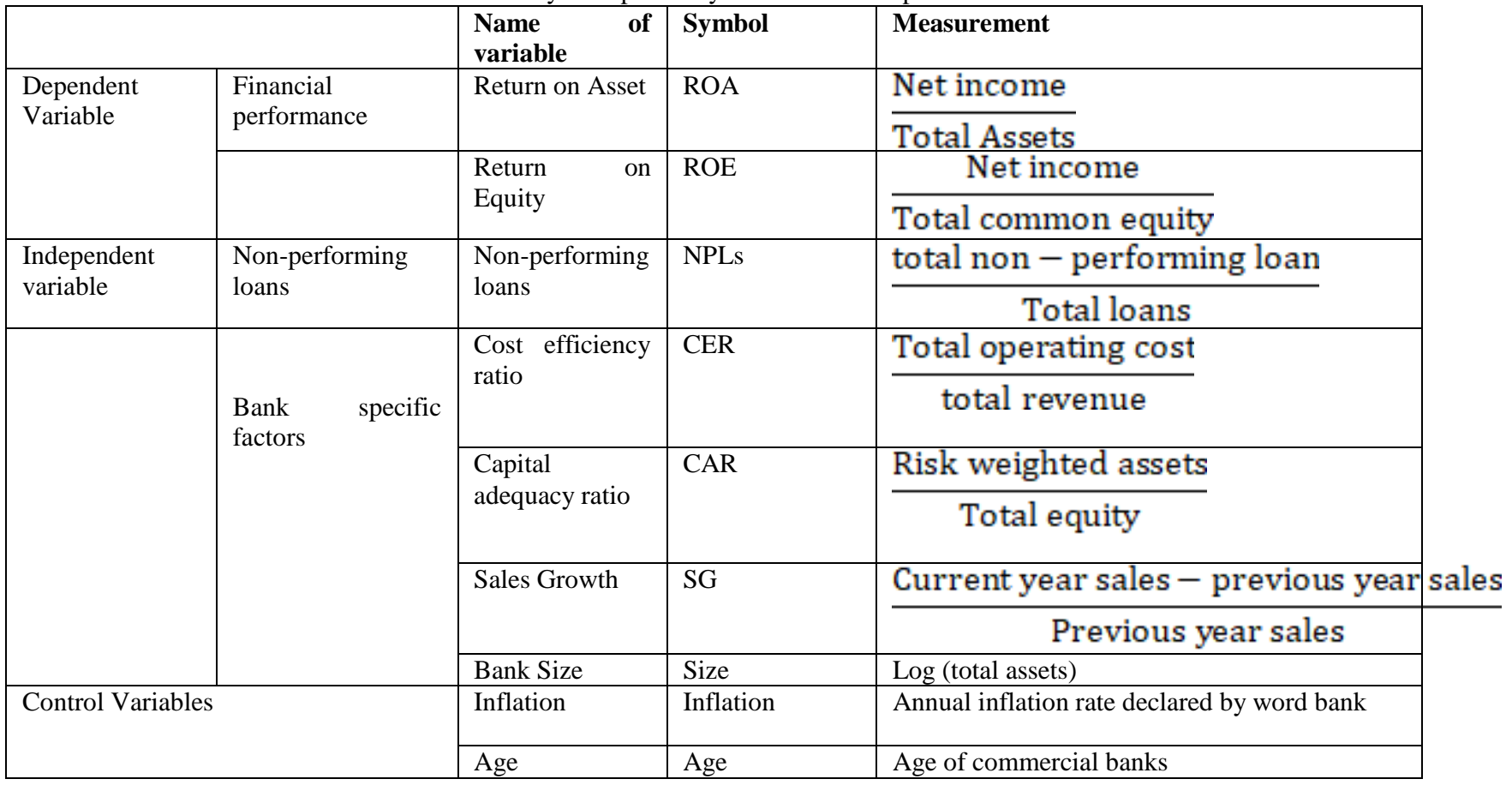




\section{Hypotheses}

H1a: There is negative and significant relationship between NPLs and ROA. $\mathrm{H} 1 \mathrm{~b}$ : There is negative and significant relationship between NPLs and ROE. $\mathrm{H} 2 \mathrm{a}$ : There is negative and significant relationship between CER and ROA. $\mathrm{H} 2 \mathrm{~b}$ : There is negative and significant relationship between CER and ROE. $\mathrm{H} 3 \mathrm{a}$ : There is positive and significant relationship between CAR and ROA. $\mathrm{H} 3 \mathrm{~b}$ : There is positive and significant relationship between CAR and ROE. H4a: There is positive and significant relationship between Size and ROA. H4b: There is positive and significant relationship between Size and ROE. H5a: There is positive and significant relationship SG between and ROA. $\mathrm{H} 5 \mathrm{~b}$ : There is positive and significant relationship SG between and ROE.

\section{Model specification}

The general form of regression model is;

Yit $=\alpha+\beta$ Xit $+\varepsilon i t$

Where

$\mathrm{I}=$ cross sectional dimension

$\mathrm{t}=$ time series dimension

Yit= dependent variable

$\mathrm{Xit}=$ dependent variables

$\alpha=$ intercept

$\beta=$ slope and $\varepsilon$ it $=$ random error term

According to Baltagi (2008) and Gujarati (1995) that in panel data the researcher uses time series data and cross sectional data in one study. He also pointed out that panel data is solution of heterogeneity that is related to different units of a one variable. According to Baltagi (2008) panel data may faces two serious threat, first is autocorrelation and secondly endogeneity. There are different test for testing autocorrelation but "Wooldridge test" to test the autocorrelation is used in this study. The $\mathrm{p}$ - value of Wooldridge test all are zero, so it means that all p-values are less than 0.05. It means that it rejects the null hypothesis and the null hypothesis is that our data has no autocorrelation but the results shows that data has autocorrelation problem.

According to Tosuni (2013) Hausman test results probabilities can be used to test the endogeneity and null hypothesis of this test is that error are uncorrelated. They also pointed out that if the probabilities are more than 0.10 then we have failed to reject null hypothesis.

The APPENDIX (A) shows that some values of hausman test are less than 0.10 , so it means that data has the problem of endogeneity. As the two assumption of CLRM model are not meet assumptions than the results of regression are not blue. So in this study used an instrumental regression (generalized method of movement) that handles all these issues. According to Gujarati (1995) GMM handles this issue of autocorrelation and endogeneity. If pooled regression is applied then the results were biased because the coefficient results can not given accurate meaning because pool regression ignore year and cross section wise variation (Baltagi, 2008, p.13). As the number of cross sectional units $(\mathrm{N})$ is greater than the number of time series unit then regression model can be estimated by two method fixed effect and random effect models. According to Tosuni (2013) Hausman test results tell us whether fixed effect or random effect model applied. 
INSIGHTS INTO REGIONAL DEVELOPMENT

ISSN 2669-0195 (online) http://jssidoi.org/jesi/

2020 Volume 2 Number 2 (June)

http://doi.org/10.9770/IRD.2020.2.2(6)

The regression model is as follow;

\section{Model 1}

$(\mathrm{ROA})$ it $=\beta 0+\beta 1(\mathrm{NPLs}) \mathrm{it}+\beta 2(\mathrm{SIZE}) \mathrm{it}+\beta 3(\mathrm{CAR}) \mathrm{it}+\beta 4(\mathrm{CER}) \mathrm{t}+\beta 5(\mathrm{SG}) \mathrm{it}+\beta 6(\mathrm{INFR})+\beta 7(\mathrm{AGE})+\varepsilon$ it (1)

\section{Model 2}

$(\mathrm{ROE}) \mathrm{it}=\beta 0+\beta 1(\mathrm{NPLs})$ it $+\beta 2(\mathrm{SIZE}) \mathrm{it}+\beta 3(\mathrm{CAR}) \mathrm{it}+\beta 4(\mathrm{CER}) \mathrm{t}+\beta 5(\mathrm{SG}) \mathrm{it}+\beta 6(\mathrm{INFR})+\beta 7(\mathrm{AGE})+\varepsilon \mathrm{it}$

\section{Analysis}

To analyze relationship non-performing loans and some bank specific factors on the profitability, firstly, the study applies then descriptive statistics; correlation analysis and lastly the regression section describe the cause and effect relationship between these variables. Moreover $t$ test is also performed who values are less than 0.05 . It means that the mean value of both groups is significantly different from each others.

\subsection{Distribution of the data}

APPENDIX (B) shows the minimum and maximum value of ROE $-268.75,100.15$ respectively and both value lies in developed countries. It means a big variation in this pool. The average value of ROA and CAR $(0.9,13)$ respectively in both pools. CAR all values lies between 2 to 7 in developed and developing countries. There is great dispersion has been observed in the value of CER, SIZE,SG, AGE, and INF whose minimum values are $20,2,-44,5,-1$ and maximum value $126,7,110,138,10$ respectively.

\subsection{Correlation}

Correlation analysis is basically used to check the linear relationship present between the two explanatory variables or not (Brooks, 2014, p. 28). Tosuni (2013) mentioned in their study that if that sample size approaches to 100 or great than 100 then if correlation coefficient is 0.20 then correlation is significant at $5 \%$ and our both pools data are greater than 100 observations.

In APPENDIX (c) most of the variables of the study are significantly positively associated at 5\% with the financial performance but NPLs and CER are significantly negatively associated with financial performance in both pools that support literature. Control variable state has insignificance with some of the dependent, independent and control variables.

To investigate the nature of relationship between NPLs and bank-specific factors with financial performance, we estimate two models as reported in Tables 4.3 and 4.4.

\subsection{Regression analysis}

APPENDIX (D) and APPENDIX (E) presents the fixed effects model results. The coefficient were calculated by the use GMM because the issue of endogenity. Hausman test is applied to check fixed or random effect is appropriate and ho: Random effect model is appropriate but the p-value of hausman test is 0.000 for developing and developed countries for both the dependent variables ROA and ROE with all other independent variables . In other words we are failed to accept null hypothesis in both pools.

To remove the issue of endogenity, the coefficient were calculated by the use of GMM. The values of Durban Watson are 1.6552 and 2.0197 for both models. It means the problem of auto correlation is also removed in our data.

Most are variables are significant at 5\% and $1 \%$ while CAR, size and control variables are insignificant in some cases. NPLs ratio and CER are significant negative relationship with ROA and ROE in both pools regressions which support our hypothesis H1a, H1b, H2a and H2b. These results are consist with Saba, kouser and Azeem 


\section{INSIGHTS INTO REGIONAL DEVELOPMENT}

ISSN 2669-0195 (online) http://jssidoi.org/jesi/

2020 Volume 2 Number 2 (June)

http://doi.org/10.9770/IRD.2020.2.2(6)

(2012) who found that there is negative relation between NPLs, CER and financial performance of commercial banks.. According to Berger and DeYoung (1997) if a bank has poor management then it would result in poor quality loans that result in an increase in cost efficiency ratio. So it means management lacks good internal controls.

CAR is significant positively relationship with ROA and ROE in both pools but insignificant with ROE in developed countries pool. So H3a is accepted in both developing and developed countries pool but h3b only accepted in developing countries. our finding matches the findings of Masood and Ashraf (2012) who found that there is significant positive relationship between ROA and CAR while insignificant relationship exist between ROE and CAR. According to economic survey by world bank (2012) when so banks has enough capital to meet risk weighted assets then automatically financial performance is also increased.

Size is significantly negative association with ROA and ROE in both pools but insignificant with ROE in developing countries pool. So $\mathrm{H} 4 \mathrm{a}, \mathrm{H} 4 \mathrm{~b}$ are rejected and our here matched with the finding of Chimkono et al., (2016) who conclude that there is negative relation between banks size and performance. It points out that small bank has high performance as compared to large because small banks have the ability to effectively managed their assets. SG has positively relationship with all measures (ROA and ROE) of both pools, so H5a and H5b are accepted in both developed and developing countries pools. These results are consistent with Kaplan and Norton (1992) who pointed out that by increasing sales financial performance of any firm also increased. Two control variables age is insignificant linked with most depend variables and inflation is significantly negative associated with most depend variables.

\section{Conclusions}

The present study has empirically examined the impact of non-performing loans and bank specific factor on financial performance of commercial banks over the period of 2006 to 2015 . The study collected the data of four countries of Asia, where two of them are developing (India and Pakistan) and remaining two countries are developed (Japan and Saudi Arabia) and data is collected from thirty six banks. The empirical results revealed the following findings: Non-performing loan and cost efficiency ratio have significant negative effect on financial performance (ROE, ROA) of commercial banks in both pools (Asian developing and developed). Capital adequacy ratio has significant positively relationship both measures of financial performance (ROA and ROE) in both pools but have insignificance with ROE in developed countries. Sale growth has positively relationship with all measures of financial performance (ROA and ROE) of both developing and developed countries pools. Bank size has significantly negative relationship with ROA and ROE in both pools but insignificant with ROE in developing countries pool. The current study has some following recommendations: Firstly, direction process of loan approval and monitoring system of commercial banks should be strong in both developing and developed countries to reduce the high ratio of Non-performing loans in Asia. Secondly, the management of commercial banks of both pools (Asian developing and developed) should need to continuously work on operational efficiency by reducing their operational cost by effectively managing all those internal factors which are under the control of management to increase revenues.

Concerning areas of further research, the present study was only limited to investigate the impact of nonperforming loans and bank specific factors on financial performance of Asian developing and developed countries commercial banks. This study can be extended by adding more countries of Asia (not only four countries) but other researchers can also take some other continents. Another study should also be carried out by increasing the number of banks or can increasing number of years of data. 
INSIGHTS INTO REGIONAL DEVELOPMENT

ISSN 2669-0195 (online) http://jssidoi.org/jesi/

2020 Volume 2 Number 2 (June)

http://doi.org/10.9770/IRD.2020.2.2(6)

\section{References}

Adebayo, M., D. Adeyanju and S. Olabode, (2011). Liquidity Management and Commercial Banks' Profitability in Nigeria. Research Journal of Finance and Accounting, 2(8)

Akhtar, M. F., Ali, K., \& Sadaqat, S. (2011). Factors influencing the profitability of Islamic banks of Pakistan. International Research Journal of Finance and Economics, 66, 125-132.

Alshatti, A. S. (2015). The effect of credit risk management on financial performance of the Jordanian commercial banks. Investment Management and Financial Innovations, 12(1), 338-345.

Balasubramaniam, C. S. (2012). Non-performing assets and profitability of commercial banks in India: assessment and emerging issues. National Monthly Refereed Journal Of Research In Commerce \& Management, June, volume, (1), 41-52.

Baltagi, B. (2008). Econometric analysis of panel data. John Wiley \& Sons.

Berger, A. N., \& DeYoung, R. (1997). Problem loans and cost efficiency in commercial banks. Journal of Banking \& Finance, 21(6), 849870.

Brooks, C. (2014). Introductory econometrics for finance. Cambridge university press.

Chimkono, E. E., Muturi, W., \& Njeru, A. (2016). Effect of non-performing loans and other factors on performance of commercial banks in malawi. International Journal of Economics, Commerce and Management, IV, 1-15.

Delmar, F., Davidsson, P., \& Gartner, W. B. (2003). Arriving at the high-growth firm. Journal of business venturing, 18(2), $189-216$.

Gorter, M. C., \& Bloem, M. A. M. (2001). The treatment of nonperforming loans in macroeconomic statistics (No. 1-209). International Monetary Fund Growth and Firm Performance. Strategic Management Journal, 455-472.

Gujarati, D. (1995) Basic Econometrics, 3rd edn., McGraw-Hill, New York.

Kaplan, R. S. \& Norton, D. P. (1992).The Balanced Scorecard - Measures The Drive Performance. Harvard Business Review, 92105, 7179.

Karim, M. Z. A., Chan, S. G., \& Hassan, S. (2010). Bank efficiency and non-performing loans: Evidence from Malaysia and Singapore. Prague Economic Papers, 2(2010), 118-132.

Krueger, Anne O. (2000). Conflicting demands on the international monetary fund. American Economic Review 90(2), 38-42.

Lata, R. S. (2015). Non-Performing Loan and Profitability: The Case of State Owned Commercial Banks in Bangladesh. World Review of Business Research, 5(3), 171-182.

Lipunga, A. M. (2014). Determinants of profitability of listed commercial banks in developing countries: evidence from Malawi. Research Journal of Finance and Accounting, 5(6), 41-49.

Masood, O., \& Ashraf, M. (2012). Bank-specific and macroeconomic profitability determinants of Islamic banks: The case of different countries. Qualitative Research in Financial Markets, 4(2/3), 255-268.

Mausya, W. B. (2009). The impact of non-performing loans on the performance of the banking sector in Kenya. An MBA project submitted to the University of Nairobi.

Negera, W. (2012). Determinants of Non Performing Loans The case of Ethiopian Banks (Doctoral dissertation, University of South Africa).

Saba, I., Kouser, R., \& Azeem, M. (2012). Determinants of Non Performing Loans: Case of US Banking Sector. The Romanian Economic Journal, Year XV, 44.

Tosuni, G. (2013). The impact of corporate governance on the performance of financial institutions (Doctoral dissertation, Staffordshire University). 
INSIGHTS INTO REGIONAL DEVELOPMENT

ISSN 2669-0195 (online) http://jssidoi.org/jesi/

2020 Volume 2 Number 2 (June)

http://doi.org/10.9770/IRD.2020.2.2(6)

\section{APPENDIXES}

APPENDIX (A)

\begin{tabular}{crrr}
\hline \multicolumn{4}{c}{ Developed countries (ROE) } \\
\hline Variable & Fixed & Random & Prob. \\
\hline NPL & -1.38144 & -0.91854 & 0.1886 \\
CAR & 0.008182 & -0.09601 & 0.1916 \\
CER & -0.32861 & -0.23254 & 0.0012 \\
SG & 0.029615 & 0.088314 & 0.0001 \\
INFL & -0.39015 & 0.087808 & 0.0216 \\
AGE & -0.68765 & -0.00768 & 0.0066 \\
\hline
\end{tabular}

\begin{tabular}{lrrr}
\hline \multicolumn{4}{c}{ Developing countries (ROE) } \\
\hline \multicolumn{1}{c}{ Variable } & Fixed & Random & Prob. \\
\hline NPL & -0.8904 & -2.10561 & 0.9468 \\
CAR & 0.008182 & -0.09601 & 0.6395 \\
CER & -0.32861 & -0.23254 & 0.5979 \\
SG & 0.029615 & 0.088314 & 0.5599 \\
SIZE & -12.0826 & 0.382527 & 0.1095 \\
INF & -0.39015 & 0.087808 & 0.8251 \\
AGE & -0.68765 & -0.00768 & 0.2538 \\
\hline
\end{tabular}

Developed countries (ROA)

\begin{tabular}{llll}
\multicolumn{1}{c}{ Variable } & Fixed & Random & Prob. \\
\hline \multicolumn{1}{c}{ NPL } & -0.10704 & -0.14153 & 0.0946 \\
CAR & 0.034439 & 0.042175 & 0.0801 \\
CER & -0.01569 & -0.01485 & 0.6126 \\
SG & 0.007571 & 0.006379 & 0.1690 \\
SIZE & -0.83722 & -0.17166 & 0.0079 \\
INFL & -0.04208 & 0.032532 & 0.0000 \\
AGE & -0.00609 & -0.00294 & 0.8400 \\
\hline
\end{tabular}

Developed countries

\begin{tabular}{|c|c|c|c|c|c|c|c|c|}
\hline \multicolumn{5}{|c|}{ Developing countries } & \multicolumn{4}{|c|}{ Developed countries } \\
\hline Variable & Mean & Max & Min & Std. & Mean & Max & Min & Std. \\
\hline ROA & 0.9662 & 4.911 & -0.4845 & 0.9951 & 0.9864 & 10.4089 & -6.2349 & 1.9057 \\
\hline ROE & 9.4823 & 66.1649 & -13.727 & 8.610 & 7.9641 & 100.158 & -268.76 & 39.176 \\
\hline NPLs & 2.5639 & 6.200 & 0.2395 & 1.1889 & 7.206 & 64.0583 & 0.2714 & 9.6599 \\
\hline CAR & 13.617 & 26.800 & -15.00 & 3.9391 & 13.885 & 39.13 & 1.050 & 4.1834 \\
\hline CER & 68.723 & 126.003 & 20.0382 & 20.477 & 27.92 & 68.6964 & 13.0509 & 9.8081 \\
\hline SG & 1.9054 & 52.3656 & -31.709 & 12.179 & 22.171 & 109.766 & -44.859 & 20.317 \\
\hline SIZE & 6.081 & 7.1948 & 4.6111 & 0.8674 & 3.899 & 5.0019 & 2.3184 & 0.5891 \\
\hline AGE & 62.082 & 138.0 & 27.000 & 25.589 & 49.132 & 111.0 & 5.000 & 34.171 \\
\hline INF & 1.9918 & 9.8700 & -1.35 & 2.5915 & 9.4493 & 20.920 & 2.540 & 3.8914 \\
\hline
\end{tabular}


INSIGHTS INTO REGIONAL DEVELOPMENT

ISSN 2669-0195 (online) http://jssidoi.org/jesi/

2020 Volume 2 Number 2 (June)

http://doi.org/10.9770/IRD.2020.2.2(6)

APPENDIX (C)

\begin{tabular}{|c|c|c|c|c|c|c|c|c|c|}
\hline Variables & ROA & ROE & NPLs & CAR & CER & SG & SIZE & AGE & INF \\
\hline ROA & 7 & 0.76 & -0.23 & 0.18 & -0.17 & 0.14 & 0.3 & -0.01 & -0.01 \\
\hline ROE & 0.78 & & -0.38 & 0.16 & -0.2 & 0.16 & 0.3 & 0.02 & -0.17 \\
\hline NPLs & -0.62 & -0.5 & & -0.28 & 0.06 & -0.29 & -0.21 & -0.18 & 0.16 \\
\hline CAR & 0.56 & 0.3 & -0.3 & & 0.41 & -0.14 & -0.03 & -0.06 & -0.02 \\
\hline CER & -0.83 & -0.73 & 0.57 & -0.42 & & -0.13 & -0.34 & -0.31 & 0.02 \\
\hline SG & 0.38 & 0.39 & -0.32 & 0.11 & -0.35 & & 0.02 & -0.11 & 0.04 \\
\hline SIZE & -0.48 & -0.31 & 0.2 & -0.2 & 0.39 & -0.09 & & 0.1 & -0.16 \\
\hline AGE & -0.5 & -0.31 & 0.34 & -0.33 & 0.36 & -0.12 & 0.49 & & -0.14 \\
\hline INF & 0.61 & 0.41 & -0.41 & 0.45 & -0.55 & 0.14 & -0.54 & -0.37 & \\
\hline
\end{tabular}

APPENDIX (D)

\begin{tabular}{|c|c|c|c|c|c|c|}
\hline & \multirow{2}{*}{\multicolumn{3}{|c|}{$\begin{array}{c}\begin{array}{c}\text { Regression of developing } \\
\text { countries commercial banks }\end{array} \\
\text { ROA } \\
\end{array}$}} & \multicolumn{3}{|c|}{$\begin{array}{c}\text { Regression of developed } \\
\text { countries commercial banks }\end{array}$} \\
\hline & & & & & ROA & \\
\hline Variable & Coefficient & Std.Error & Prob. & Coefficient & Std.Error & Prob. \\
\hline C & 11.016 & 5.3891 & 0.0427 & 3.1163 & 0.2305 & 0.0000 \\
\hline NPL & -0.0774 & 0.0303 & $0.0118^{* *}$ & -0.0346 & 0.0129 & $0.0101 * *$ \\
\hline CER & -0.0316 & 0.0116 & $0.0095^{*}$ & -0.014 & 0.0026 & $0.0095^{*}$ \\
\hline CAR & 0.0332 & 0.0148 & $0.0363^{* *}$ & 0.0156 & 0.0051 & $0.0027^{*}$ \\
\hline SG & 0.0505 & 0.0132 & $0.0163 * *$ & 0.0014 & 0.0006 & $0.0289 * *$ \\
\hline SIZE & -2.723 & 1.8046 & $0.0919 * * *$ & -0.1443 & 0.0645 & $0.0271 * *$ \\
\hline AGE & 0.1235 & 0.0899 & 0.1245 & -0.0111 & 0.0028 & $0.0001 *$ \\
\hline INF & -0.0208 & 0.0091 & $0.0428 * *$ & -0.0113 & 0.17596 & 0.1785 \\
\hline $\begin{array}{l}\text { Durbin- } \\
\text { Watson stat }\end{array}$ & & 1.6552 & & & 2.0197 & \\
\hline R-squared & & 0.7536 & & & 0.6606 & \\
\hline $\begin{array}{l}\text { Adjusted R- } \\
\text { squared }\end{array}$ & & 0.7112 & & & 0.5966 & \\
\hline F-statistics & & 8.469 & & & 11.3979 & \\
\hline $\operatorname{Prob}(F-$ stat $)$ & & 0.0000 & & & 0.0000 & \\
\hline $\begin{array}{l}\text { Hausemen } \\
\text { test(chi- }\end{array}$ & & 13.4503 & & & 11.031 & \\
\hline $\begin{array}{l}\text { P-value(chi- } \\
\text { square) }\end{array}$ & & 0.0000 & & & 0.0000 & \\
\hline J-statistic & & 0.224 & & & 0.3598 & \\
\hline $\begin{array}{l}\operatorname{Prob}(J- \\
\text { statistic) }\end{array}$ & & 0.0769 & & & 0.5486 & \\
\hline
\end{tabular}


INSIGHTS INTO REGIONAL DEVELOPMENT

ISSN 2669-0195 (online) http://jssidoi.org/jesi/

2020 Volume 2 Number 2 (June)

http://doi.org/10.9770/IRD.2020.2.2(6)

APPENDIX (E)

\begin{tabular}{|c|c|c|c|c|c|c|}
\hline & \multicolumn{3}{|c|}{$\begin{array}{c}\text { Regression of developing } \\
\text { countries commercial banks }\end{array}$} & \multicolumn{3}{|c|}{$\begin{array}{c}\text { Regression of developed } \\
\text { countries commercial banks }\end{array}$} \\
\hline & \multicolumn{3}{|c|}{ ROE } & \multicolumn{3}{|c|}{ ROE } \\
\hline Variable & Coefficient & Std.Error & Prob. & Coefficient & Std.Error & Prob. \\
\hline $\mathbf{C}$ & 13.03027 & 65.187 & 0.8418 & 66.8335 & 8.3339 & 0.0001 \\
\hline NPL & -1.17270 & 0.4621 & $0.0121 * *$ & -0.4892 & 0.2010 & $0.0115^{* *}$ \\
\hline CER & -1.19700 & 0.4729 & $0.0123 * *$ & -0.2652 & 0.0181 & $0.0000^{*}$ \\
\hline CAR & 1.95775 & 0.8959 & $0.0303 * *$ & 0.02979 & 0.1001 & 0.7665 \\
\hline SG & 0.27620 & 0.13586 & $0.0436 * *$ & 0.05232 & 0.0197 & $0.0089 *$ \\
\hline SIZE & -15.9118 & 21.45493 & 0.4594 & -5.2219 & 2.034 & $0.0113 * *$ \\
\hline INF & -1.69060 & 0.6253 & $0.0076^{*}$ & -0.0237 & 0.0021 & $0.0102 * *$ \\
\hline AGE & 1.65906 & 1.45817 & 0.2569 & -0.2931 & 0.4040 & 0.3620 \\
\hline $\begin{array}{l}\text { Durbin-Watson } \\
\text { stat }\end{array}$ & \multicolumn{3}{|c|}{1.6849} & \multicolumn{3}{|c|}{1.9951} \\
\hline R-squared & \multicolumn{3}{|c|}{0.51847} & \multicolumn{3}{|c|}{0.7617} \\
\hline $\begin{array}{l}\text { Adjusted R- } \\
\text { squared }\end{array}$ & \multicolumn{3}{|c|}{0.4453} & \multicolumn{3}{|c|}{0.7167} \\
\hline F-statistics & \multicolumn{3}{|c|}{61.3431} & \multicolumn{3}{|c|}{61.3431} \\
\hline $\operatorname{Prob}(F-s t a t)$ & \multicolumn{3}{|c|}{0.0000} & \multicolumn{3}{|c|}{0.0000} \\
\hline $\begin{array}{l}\text { Hausemen } \\
\text { test(chi- sq) }\end{array}$ & \multicolumn{3}{|c|}{56.3705} & \multicolumn{3}{|c|}{56.3705} \\
\hline $\begin{array}{l}\text { P-value(chi- } \\
\text { square) }\end{array}$ & \multicolumn{3}{|c|}{0.0000} & \multicolumn{3}{|c|}{0.0000} \\
\hline J-statistic & \multicolumn{3}{|c|}{2.0203} & \multicolumn{3}{|c|}{5.2041} \\
\hline $\begin{array}{l}\operatorname{Prob}(J- \\
\text { statistic) }\end{array}$ & \multicolumn{3}{|c|}{0.052} & \multicolumn{3}{|c|}{0.0744} \\
\hline
\end{tabular}

Significance level: $*$ significant at 1 percent; $* *$ significant at 5 percent; $* * *$ significant at 10 percent. 
INSIGHTS INTO REGIONAL DEVELOPMENT

ISSN 2669-0195 (online) http://jssidoi.org/jesi/

2020 Volume 2 Number 2 (June)

http://doi.org/10.9770/IRD.2020.2.2(6)

Asima SIDDIQUE is PhD Scholar at Department of Management Science, Comsats University, Islamabad, Pakistan

ORCID ID: https://orcid.org/0000-0002-1075-2332

Prof. Dr. Omar MASOOD (PhD UK) is CEO OM International Learning Partner Asia-e-University, Malaysia. He is also Professor at School of Accountancy and Finance, University of Lahore Islamabad, Pakistan. He is former Director of the Centre of Islamic Banking and Finance at the Royal Docks Business School, University of East London, United Kingdom. He had worked with financial advisors like Goldman Sachs. He is a lead advisor and trainer in the area of Islamic banking and finance worldwide, to financial as well as academic institutions. He is a founding member of Research Centers in Malaysia. Dr. Masood supervises PhD dissertations in the areas of banking, finance, corporate financial management, risk management, fund management, banking regulations, Islamic banking, international business and other finance, accounting and management related subjects, with a number of successful completions. He holds visiting professorships in universities all over the world, and has served as an advisor/consultant to a number of governments including the Turkish and Saudi Arabian. Dr. Masood has authored over a hundred peer reviewed research papers which have been published in international journals and presented at conferences. A number of his papers have been listed as highly recommended and most read by leading publishers. He has also authored a number of books, including the bestselling "Truth about the Global Financial Crisis" and the text book "Multiplying Money through Financial Management".

ORCID ID: $\underline{\text { https://orcid.org/0000-0001-5481-4032 }}$

Kiran JAVARIA is Lead Learning Advisor of OM International Learning Partner Asia-e-University, Malaysia. She is also Lecturer at School of Accountancy and Finance, University of Lahore, Islamabad Campus, Pakistan. Her specialization is in finance, Islamic banking and research based topics. Her PhD is in Islamic Banking \& Finance from Asia e University, Kuala Lumpur, Malaysia. She has authored several research papers which have been published in some leading international journals and presented at conferences. Her recent publications are in international journals i.e. "Problems and Perspectives in Management" and "Global Advanced Research Journals". Her recent publications have been highly recommended and cited globally.

ORCID ID: https://orcid.org/0000-0002-6147-5283

\section{Dinh Tran Ngoc HUY}

MBA Banking University of Ho Chi Minh city Vietnam- International University of Japan, Japan Dtnhuy2010@gmail.com

ORCID ID: https://orcid.org/0000-0002-2358-0699

Register for an ORCID ID:

https://orcid.org/register

Copyright (C) 2020 by author(s) and VsI Entrepreneurship and Sustainability Center

This work is licensed under the Creative Commons Attribution International License (CC BY).

http://creativecommons.org/licenses/by/4.0/

(c) (i) 